\title{
Memahami "Kebenaran" dalam The Act of Killing Melalui Gestur dan Fitur
}

\author{
Renta Vulkanita Hasan ${ }^{1, a)}$ \\ ${ }^{1}$ Universitas Jember \\ ${ }^{a)}$ korespondensi penulis : rentavulkanita.sastra@unej.ac.id \\ DOI:https://doi.org/10.18196/jkm.101008
}

Article Info

Article history:

Received 5Okt 2018

Revised 190kt 2018

Accepted 6Nov2018

\begin{abstract}
One of the ways that the audience can capture the coherence of the film as seen and drawn is by imagining that, at certain times, there are elements that can be identified and serve as a means to read events in a documentary. These elements are: (1) gesture; and (2) features. Gesture occupies a position as one of the instructional texts that indicates the sequence of events in a film through things that are attached to the actor's body. In addition to gestures, other elements that influence how filmic clues can be read by the audience are the features. Features are artistic elements that significantly show the identity of the actor, place, time, and relationship with the events that occurred. In The Act of Killing, the truth of the event is narrated through the performative scene of Anwar Congo which is full of gesture and features. This study findings that the elements of gestures and features in The Act of Killing provide clues for the audience to understand the truth through reading it.
\end{abstract}

Keywords: Truth, Documentary, Gesture, Feature, Performative

\section{ABSTRAK}

Salah satu cara yang dapat dilakukan oleh penonton untuk menangkap koherensi film sebagai yang terlihat dan yang tergambar adalah dengan membayangkan bahwa, pada saat tertentu, terdapat unsur-unsur yang dapat diidentifikasi dan berfungsi sebagai sarana untuk membaca peristiwa dalam sebuah dokumenter. Unsur-unsur tersebut adalah: (1) gestur; dan (2) fitur. Gestur menempati posisi sebagai salah satu teks petunjuk yang mengindikasikan runtutan peristiwa dalam sebuah film melalui hal-hal yang melekat pada tubuh aktor. Selain gestur, unsur lain yang turut memengaruhi bagaimana petunjuk filmis dapat dibaca oleh penonton adalah dengan adanya fitur. Fitur merupakan elemen artistik yang secara signifikan menunjukkan identitas pelaku (aktor), tempat, waktu, dan hubungannya dengan peristiwa yang terjadi. Dalam The Act of Killing, kebenaran peristiwa dinarasikan melalui adegan performatif Anwar Congo yang sarat akan unsur gestur dan fitur. Penelitian ini menghasilkan temuan bahwa unsur gestur dan fitur dalam The Act of Killing memberikan petunjuk bagi penonton untuk memahami kebenaran melalui pembacaan terhadapnya.

Kata kunci: Kebenaran, Dokumenter, Gestur, Fitur, Performatif 


\section{PENDAHULUAN}

Membaca kata "Jagal" pada scene pembuka dokumenter karya Joshua Oppenheimer (2012) membawa pemahaman kepada suatu aktivitas yang berasosiasi dengan pembunuhan. Pemahaman semakin diperkuat oleh narasi berupa tulisan yang menjelaskan bahwa ini adalah sebuah dokumenter yang berkisah tentang aktivitas pembunuhan di Medan terkait peristiwa G30S/PKI 1965. The Act of Killing atau Jagal adalah judul dokumenter ini. Dokumenter yang berkisah tentang kehidupan

Page $\mid 90$ beberapa Jagal (pembunuh bayaran) pada rentang tahun 1965-1966. Mereka, pada saat itu, bertugas untuk membunuh orang-orang yang dicurigai (bahkan dituduh) terlibat dalam gerakan 30 september 1965 (G30S/PKI). G30S/PKI adalah sebutan bagi peristiwa yang pernah terjadi Indonesia dan mengakibatkan kekacauan politik, bahkan kemanusiaan. ${ }^{\mathrm{i}}$

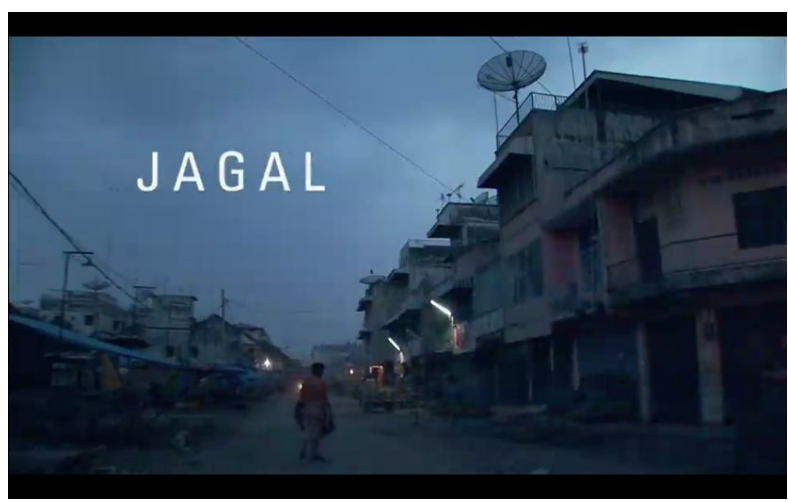

Gambar 1. Frame 1(Sumber: The Act of Killing, Oppenheimer: 2012. Timeline: 00.01.58-00.02.06).

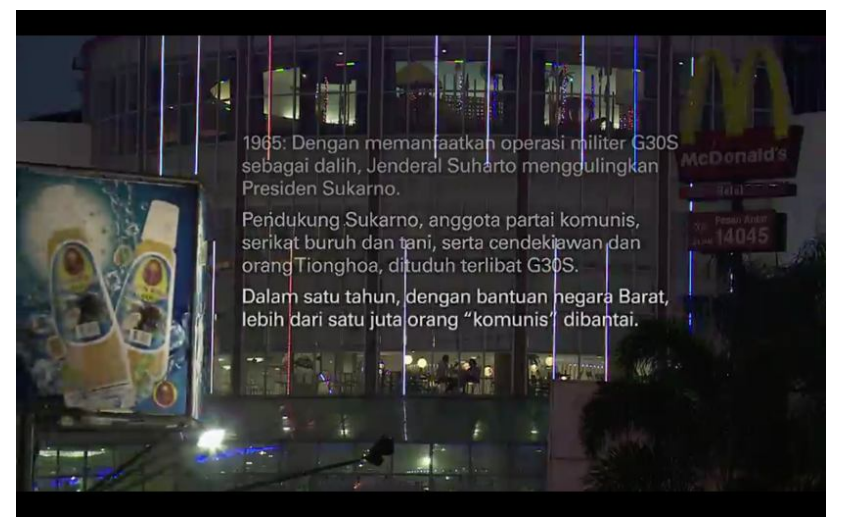

Gambar 2. Frame 2 (Sumber: The Act of Killing, Oppenheimer: 2012. Timeline: 00.02.16-00.02.37) 
Vol. 10 No. 2

November 2018

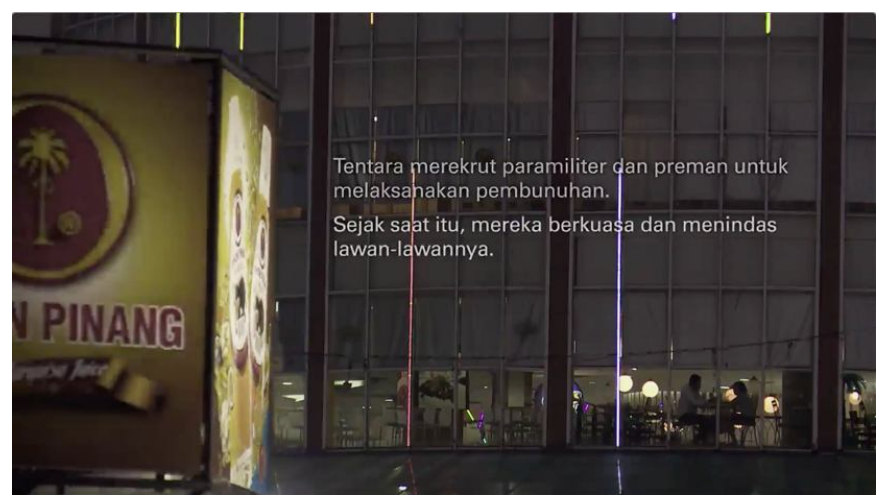

Page $\mid 91$

Gambar 3. Frame 3 (Sumber: The Act of Killing, Oppenheimer: 2012. Timeline: 00.02.52-00.03.05).

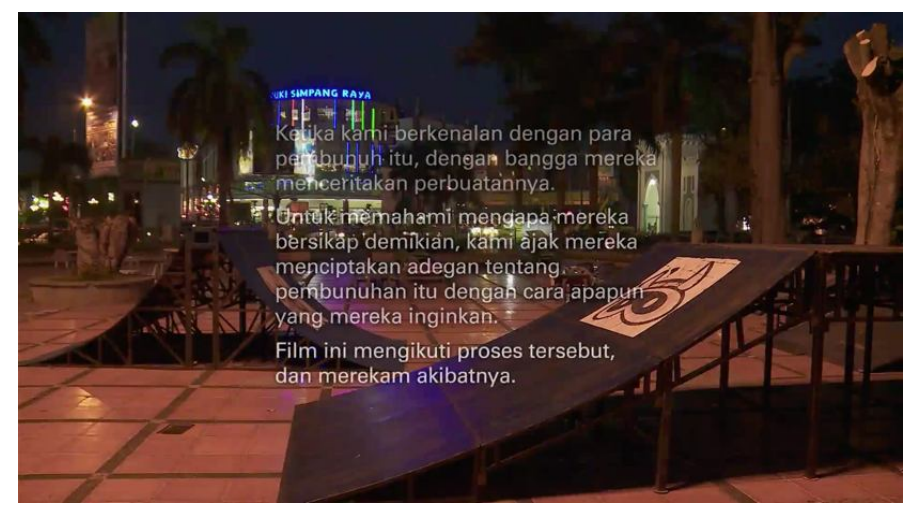

Gambar 4. Frame 4 (Sumber: The Act of Killing, Oppenheimer: 2012. Timeline: 00.03.10-00.03.33)

Para jagal ini kemudian menjadi aktor dalam dokumenter dengan tujuan untuk menceritakan kembali pengalaman mereka sebagai pembunuh melalui performativitas. Performativitas ditunjukkan melalui pengadeganan ulang (reenactment) dalam sebuah pertunjukan teatrikal. Beberapa tokoh yang pernah terlibat dan memiliki peran penting saat peristiwa itu, dimunculkan dalam dokumenter ini. Namun di antara beberapa tokoh itu, ada tokoh yang difokuskan pada dokumenter ini, yaitu Anwar Congo (Anwar). Anwar adalah salah satu pelaku jagal yang berprofesi sebagai mantan preman bioskop yang kesehariannya saat itu bekerja mengedarkan tiket gelap bioskop di Medan.

Dalam dokumenter ini, Anwar Congo menampilkan pola gestur yang didukung oleh fitur untuk mengisyaratkan peristiwa. Narasi kemudian dipahami melalui pembacaan terhadap dua unsur, yaitu gestur dan fitur. Gestur atau disebut juga sebagai isyarat gerak tubuh memiliki pengertian sebagai aktivitas, produk atau aktualisasi energi, dan gerak (Chare dan Watkins, 2015). Istilah gestur mencakup berbagai fenomena, khususnya berkaitan dengan pengertiannya sebagai citra intrinsik bahasa (McNeill, 2016). Gestur juga dapat disebut sebagai tindakan yang terlihat sebagai bagian dari bahasa yang berbentuk ucapan (Kendon, 2004). Bahasa tidak dapat dipisahkan dari gestur sebagai isyarat gerak tubuh karena gestur mengatur ucapan sebagai bahasa verbal dan bahasa verbal tidak dapat dipisahkan dari isyarat gerak tubuh. Gestur bukanlah sesuatu isyarat istimewa dalam tingkah laku manusia karena itu merupakan gerakan sehari-hari yang biasa dilakukan dalam setiap aktivitas manusia.

Dalam film, khususnya dokumenter, gestur secara spesifik mengarah kepada konteks setiap gerakan manusia. Gestur merupakan gerak manusia yang terjadi dan terlihat sebagai akibat dari gerakan tubuh tertentu, seperti: wajah (memutar mata, mengedip), leher (mengangguk, menggelengkan kepala), tangan (menuding, melambai, melamun), bahu (mengangkat bahu), lutut (jongkok), batang tubuh (membungkuk, memunggungi seseorang), atau kombinasi daripadanya. Terdapat 4 klasifikasi gestur dalam kaitannya dengan gerak yang terdapat dalam teks film. Klasifikasi itu dibuat oleh Kendon berdasarkan pemahaman terhadap gerakan alami yang dilakukan oleh manusia 
dalam merespon situasi (Kendon, 2004). Gestur dilihat sebagai gerak yang didefinisikan sebagai berikut: (1) Gerak dilihat sebagai perilaku yang disengaja, sadar, dan diatur oleh niat untuk mengatakan sesuatu atau untuk berkomunikasi. Artinya, gerak yang dilakukan merupakan gerakan yang diatur dalam naskah untuk mengisi plot pada film. Contoh: ekspresi mimical pada wajah dan pola tangan yang bergerak secara simultan dan kemudian diikuti suara tangis untuk mengungkapkan kesedihan; (2) Gerak dilihat sebagai perilaku yang berkaitan dengan upaya mempertahankan atau

Page 92 mengubah posisi atau orientasi tubuh kepada sikap tertentu. Artinya, gerakan ini mengikuti pola dialog dan plotting untuk memenuhi adegan tertentu. Contoh: aktor berjalan mengelilingi aktor yang lain, kemudian menepuk pundak si aktor lain; (3) Gerak dilihat sebagai yang aktivitas yang melibatkan petunjuk tubuh dalam melakukan manipulasi objek, seperti pakaian dan perkakas. Artinya, perilaku ini dilakukan oleh aktor secara sengaja berdasarkan petunjuk narasi, namun tidak bersifat sebagai upaya komunikatif. Contoh: aktor mengenakan baju, aktor mengambil gelas, dan memindahkan dari satu meja ke meja yang lain; (4) Gerak dilihat sebagai yang aktivitas yang menunjukkan kecemasan atau tindakan tiba-tiba. Artinya, ada hal yang membuat si aktor atau narasumber teringat akan peristiwa yang membangkitkan emosinya secara tiba-tiba. Contoh: menundukkan kepala lalu menangis dan megusap air mata; memejamkan mata sambil menggelengkan kepala.

Selain gestur, unsur lain yang turut memengaruhi bagaimana petunjuk filmis dapat dibaca oleh penonton adalah dengan adanya fitur. Fitur merupakan elemen artistik yang secara signifikan menunjukkan identitas pelaku (aktor), tempat, waktu, dan hubungannya dengan peristiwa yang terjadi. Melalui fitur, koherensi film dapat ditangkap oleh penonton secara sinkronis dengan menggabungkan elemen properti yang melekat pada pelaku (aktor), tempat, dan waktu. Pada tingkat yang sangat dasar, fitur menjadikan film sebagai gambar bergerak dengan tampilan menyerupai situasi dan lokasi aslinya. Tampilan itu meliputi konteks geografis, historis, sosial budaya dan detail material terkait, termasuk kerangka fisik di mana narasi film diceritakan melalui rangkaiannya. Fitur secara khusus juga berfungsi dalam mengidentifikasi karakter, menyempurnakan, dan mengkonsentrasikan sisi psikologis aktor untuk dapat secara total memainkan peran tertentu. Adapun unsur-unsur dari fitur yang berkontribusi dalam mengkonsentrasikan atau membangun sisi psikologis aktor adalah: (1) Musik dan pencahayaan. Melalui musik dan teknik pencahayaan, aktor dibantu untuk menciptakan nuansa tempat yang dapat membangkitkan suasana hati. Dengan demikian, efek yang dihasilkan oleh musik maupun Teknik pencahayaan ini dapat membangkitkan emosi dan keinginan aktor untuk melengkapi narasi. Fitur berlaku pula dalam sebuah dokumenter karena setiap dokumenter juga memiliki unsur mise-enscène, yang bertindak sebagai media representasi tentang lokasi nyata di mana peristiwa itu terjadi atau menciptakan lokasi yang sepenuhnya buatan di mana peristiwa itu pernah terjadi. (2) Properti, lokasi, dan tata letaknya. Keduanya secara bersama menciptakan ruang bagi aktor untuk menubuh dan menghayati karakter yang diperankan. Dalam dokumenter, membawa kembali pelaku ke tempat di mana peristiwa pernah terjadi akan mebangkitkan sisi psikologis sehingga cara bertuturnya barangkali menjadi lebih emosional. Pemilihan dan peletakkan properti secara rekonstruktif juga sangat membantu dalam penciptaan petunjuk dalam suatu dokumenter. Susunan properti akan menunjukkan tentang lokasi peristiwa, bahkan hingga kronologi peristiwa itu terjadi. Kronologi dapat dibaca sebagai petunjuk melalui peran aktor yang terlibat dalam penggunaan properti.

\section{PEMBAHASAN}

Membaca gestur dan fitur dalam frame-frame yang memuat adegan Anwar Congo, secara metodologis menggunakan pendekatan film-kognitif.Pendekatan film-kognitif memiliki urgensi untuk membaca jalan cerita dan menciptakan makna terhadap dokumenter melalui pemahaman (understanding). Artinya, pemahaman hubungan antara film dan penonton, yang melaluinya telah banyak menghasilkan aktivitas untuk mengeksplorasi sarana tentang aktivitas isyarat dari narasi film dalam memberi dan menerima tanggapan dari penonton (Plantinga, 2006). Merujuk pada Bordwell (1991),interpretasi menjadi hal penting yang digunakan untuk mengungkap makna pada proses penafsiran seseorang terhadap suatu film, sekaligus sebagai alat kritik yang mendorong cara berpikir tentang bagaimana film memberikan kesempatan bagi penonton untuk menghibur dan bertindak sebagai ruang imajinatif (Bordwell, 1991). Ini menjadi penting ketika interpretasi seseorang dalam memaknai sebuah dokumenter dianggap menjadi salah satu penentu perkara kebenaran filmis pada 
Vol. 10 No. 2

November 2018

dokumenter. Pemahaman melalui pendekatan film-kognitif adalah suatu proses yang melibatkan halhal yang bersifat tekstual maupun kontekstual melalui proses belajar (skemata). Artinya, proses belajar dalam memahami film dapat diartikan sebagai suatu struktur pengetahuan yang melibatkan proses belajar melalui berbagai instrumen, baik itu rangkaian teks maupun pengalaman diri yang berguna sebagai petunjuk untuk sebuah konklusi narasi secara komprehensif. Sebagai sebuah proses pemahaman, proses belajar berpusat pada aktivitas kognitif manusia (penonton). Aktivitas kognitif manusia secara spesifik memiliki variasi yang bersifat kultural dan membawanya sebagai prinsip yang general. Artinya, dalam praktik pemahaman penonton terhadap rangkaian peristiwa yang ditampilkan oleh petunjuk filmis mampu bersifat lintas budaya dan mencapai penalaran induktif.

Pemahaman terhadap Anwar dimulai dengan memperhatikan scene 1 pada timeline 00.00.4800.00.56, yang menampilkan sosok Anwar untuk pertama kalinya. Tampak sosok Anwar memakai busana serba hitam dan berdiri di depan air terjun bersama rekannya Herman Kotto dan para penari. Mengamati unsur gestural yang melekat pada Anwar dan fitur yang berada di sekitarnya, terlihat beberapa petunjuk yang dimulai dari gestur representasional yang pertama adalah ekspresif. Ekspresif merupakan ciri gestural representasional yang melekat pada wajah seseorang. Desmond Morris (2002) mengatakan bahwa ekspresif adalah tipe gestur yang melekat pada hampir semua pria, yang dapat terjadi di mana saja, saat berinteraksi satu sama lain. Gestur ekspresif termasuk sinyal penting dari gerak wajah dan sangat penting dalam interaksi manusia sehari-hari (Morris, 2002: 24). Pertama, terungkap mengapa dalam adegan ini Anwar memperlihatkan gestur ekspresif dengan menutup kedua mata, kepala sedikit terangkat, dan mulut terbuka. Aspek tematik menjadi pembahasan pertama yang akan mengungkap gestur eksresif Anwar.

A

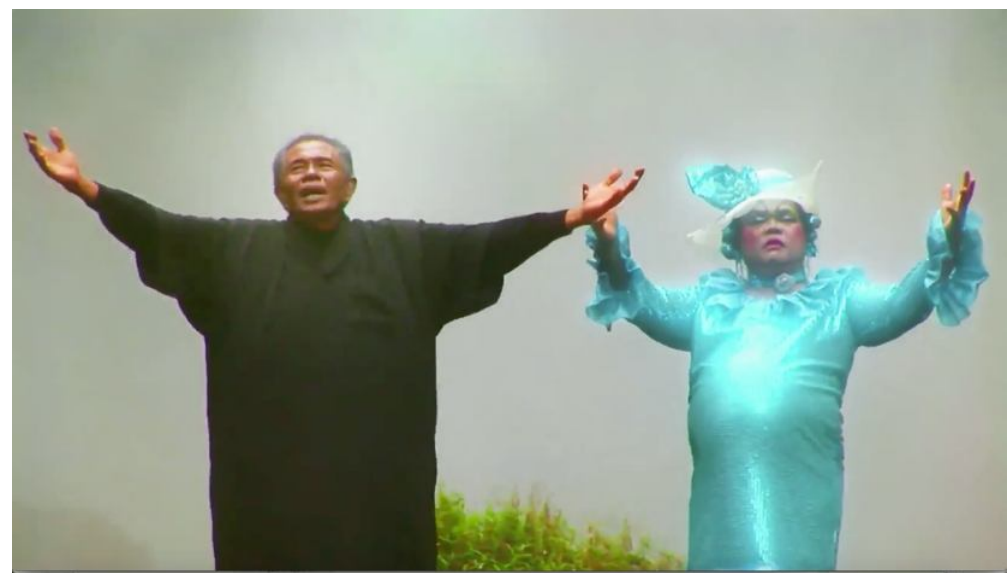

(a)

B

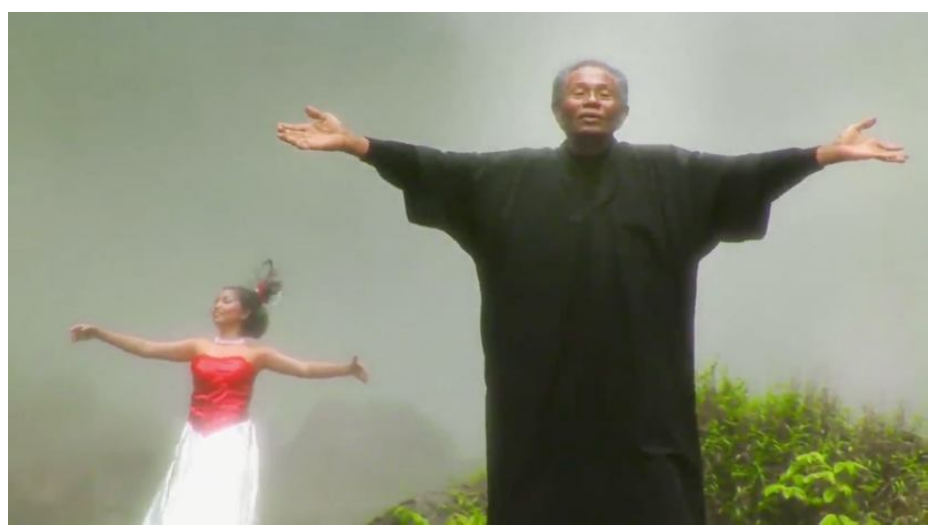

(b)

Gambar 5. a) Frame Anwar Congo (berbaju hitam) dan Herman Kotto (berbaju hijau). b) Frame Anwar Congo dan seorang penari (berbaju merah putih) (Sumber: The Act of Killing, Oppenheimer: 2012. Timeline: 00.01.19 dan 00.01.33) 
Gestur ekspresif Anwar dilakukan dengan sengaja untuk tujuan pertunjukan. Kesengajaan gestur ekspresif yang ditunjukkan Anwar juga memiliki petunjuk berupa fitur (1) Suara, yaitu terdengarnya teriakan seseorang. Teriakan itu mengarahkan agar Anwar atau orang-orang yang berada di dalam frame untuk mengikuti. Teriakan itu berbunyi:

"Yaaak! tahan...tahan...!"

(2) Properti dan lokasi, menunjukkan busana khusus yang dipakai Anwar dan orang-orang Page 94 disekitarnya, serta lokasi air terjun dan bebatuan (outdoor setting).

Wajah dengan mata terbuka dan kemudian tertutup, demikian pula dengan mulut yang terbuka kemudian menjadi setengah tertutup memberi petunjuk tentang perihal yang sedang dirasakan oleh Anwar. Pemahaman terhadap apa yang sedang dirasakan oleh Anwar difokuskan pada mata dan mulut, di mana keduanya merupakan petunjuk filmis tentang tema performatif yang ingin disampaikan Anwar. Ini juga menjadi petunjuk terkait bagaimana penonton menalar sebuah adegan sebagai upaya dalam membaca teks film. Dalam mempertimbangkan jenis penalaran penonton yang mengatur pemetaan terhadap pembacaan teks film, terdapat asumsi dasar tentang kebutuhan penonton untuk menemukan isyarat berdasarkan beberapa fakta yang tercantum disepanjang teks. Asumsi ini menyebutkan bahwa pengalaman penonton terhadap rangkaian fabula dan syuhzet sebagai penampil teks yang potensial akan menghasilkan dua hipotesis regulatif utama, yaitu koherensi minimal dan mimesis, yang notabene mengatur makna potensial dalam hubungan antara makna satu dengan yang lain (Bordwell, 1991). Bordwell (1991) menjelaskan bahwa pengalaman akan menghasilkan koherensi dasar atau minimal dan bersifat mimesis. Artinya, pengetahuan yang dibawa oleh penonton pada saat mengalami, mendorong pembacaan terhadap narasi film secara praktis berdasarkan petunjuk-petunjuk filmis yang menyerupai peristiwa yang pernah terekam dalam ingatannya.Dalam kasus menonton dokumenter, harus ditekankan bahwa hipotesis tersebut memiliki ketentuan, yaitu: fungsi dalam lembaga tertentu dan pada waktu tertentu. Ketentuan dalam situasi tersebut dapat dianalogikan melalui alur konseptual yang disusun secara internal, dengan menyusun seperangkat hubungan antara jenis agen, objek, tindakan, dan keadaan lembaga. Agen merupakan item yang disebut sebagai penonton. Objek merupakan item yang disebut sebagai teks filmis. Tindakan merupakan item yang disebut sebagai petunjuk filmis melalui fabula dan syuzhet. Lembaga merupakan item yang membingkai keseluruhan perangkat, yang dalam hal ini adalah dokumenter itu sendiri yang disebut sebagai lembaga. Dalam hipotesis, agen (dalam hal ini adalah penonton) akan mengamati objek dan tindakan dalam dokumenter. Objek dalam hal ini akan menyajikan hal penting berupa data, yang dalam kasus konkret selama proses menonton, dapat digunakan oleh agen untuk mengisi slot yang dibiarkan kosong di sepanjang tindakan (petunjuk filmis). Data ini berguna untuk menentukan sejauh mana penonton merasakan pengalaman melalui kegiatan melengkapi slot-slot petunjuk melalui struktur skematik. Cara kerja struktur skematiknya dimulai dari dengan bentuk asumsi di bawah standar dan kemudian menyesuaikannya dengan situasi nyata (misalnya, slot tentang pembunuhan dapat diisi dengan tampilan artistik berupa darah atau senjata tajam, atau slot figur penjahat dapat diisi oleh figure preman), sehingga dengan melihat elemen artistik dan figur yang ditampilkan di sepanjang plot, maka penonton dapat dengan mudah mengenali slot-slot yang menampilkan narasi tertentu.

Kemudian, pembacaan difokuskan pada unit gestur secara keseluruhan pada skema tersebut. Tahap pembacaan dimulai dengan tatapan yang mengarah pada mata dan mulut Anwar yang awalnya terbuka. Gerakan mata dan mulut Anwar simultan dengan instruksi suara yang terdengar. Selama 10 detik mata dan mulut Anwar terbuka, lalu perlahan tertutup. Tatapan mata mengikuti arah tatapan mata dan mulut Anwar yang setengah mendongak ke atas. Scene tersebut menampilkan pola editing yang fokus pada dua figure, yaitu Anwar dan Herman. Namun pengamatan fokus terhadap Anwar sehingga arah tatapan tetap tertuju pada Anwar. Pemahaman berlangsung dan dimulai dengan menangkap pola fitur di sekitar Anwar. Fitur itu adalah: baju Anwar berbentuk jubah berwarna hitam dan air terjun. Pemahaman lalu berkembang kepada level selanjutnya untuk menangkap isyarat representasional dengan melihat pergerakan kepala dan tangan anwar. Namun karena fokus pembacaan masih pada level ekspresif, maka tatapan hanya diarahkan pada wajah Anwar untuk mengamati mata dan mulut yang memiliki pergerakan. Setelah itu pembacaan berlanjut pada level selanjutnya untuk melihat gestur dan konteksnya. Tatapan difokuskan pada air terjun dan busana Anwar. Adanya fitur air terjun dalam scene Anwar memberikan petunjuk tentang tema cerita yang ingin disampaikan Anwar, demikian juga perihal kostum. Kostum berbentuk jubah dan berwarna hitam yang dikenakan Anwar di depan air terjun juga mengindikasikan tentang perihal yang tema tertentu yang ingin dibangun Anwar. Tema itu nampaknya adalah tema fiktif yang merepresentasikan 
Vol. 10 No. 2

November 2018

sesuatu dari kehidupan nyata. Kemudian pembacaan dilanjutkan kepada level relasional untuk memperoleh kesimpulan berdasarkan korelasi antara teks dan konteks yang melekat pada Anwar. Mata dan mulut yang terbuka lebar mengisyaratkan kekaguman terhadap sesuatu. Jika dikaitkan dengan properti dan lokasi, kekaguman ditujukan kepada sesuatu di sekelilingnya, mungkin itu kepada air terjun atau sekelompok perempuan yang berdandan dan menari di sekitar Anwar. Kemudian mata dan mulut yang perlahan tertutup mengisyaratkan akan penghayatan atau upaya Anwar untuk merasakan sesuatu. Unsur yang dapat dirasakan dalam artian sifat atau nilai, adalah unsur yang dapat diterima oleh sistem pancaindera, baik itu penglihatan maupun pendengaran. Apabila membaca gerakan mata dan mulut Anwar, ditemukan korelasi antara wujud dan nilai unsur yang sedang dirasakan oleh Anwar. Mata dan mulut yang tertutup mengisyaratkan Anwar sedang merasakan nilai dari wujud dan suara air terjun atau bahkan juga terhadap wujud dan suara sekelompok perempuan disekitarnya. Isyarat utama dari pergerakan mata dan mulut Anwar dalam scene ini adalah tentang kekaguman yang ditunjukkan melalui gestur ekspresif.

Gestur ekspresif Anwar yang lain muncul pada timeline 00.10.08-00.11.12. Anwar menunjukkan ekspresi wajah ceria yang diisyaratkan dengan mulut terbuka, tersenyum, dan bahkan meringis, juga mata yang terpejam dan terbuka saat berjoget. Selain itu, mata yang terbuka dan mulut tertawa saat memeragakan pembunuhan juga menunjukkan keceriaan pada diri Anwar. Gestur ekspresif ini menunjukkan aspek konstruksional yang artinya gestur dibangun bersamaan dengan pertunjukan adegan rekonstruksi. Dalam scene itu, Anwar menceritakan dan memperagakan pembunuhan dengan diselingi tawa bahkan berjoget. Busana yang digunakan pun memiliki bentuk, warna, dan motif yang mengisyaratkan keceriaan. Begitu juga dengan perlakuan Anwar terhadap properti yang digunakan untuk reka ulang. Anwar berbicara menghadap kamera sambil melilitkan kawat ke lehernya sendiri. Gestur yang diciptakan Anwar secara langsung mengisyaratkan peristiwa masa lalu yang pernah dilakukan merupakan peristiwa wajar. Termasuk fitur busana yang dipilih Anwar dalam adegan performatif (reka ulang) ini memperkuat isyarat tersebut. Dengan demikian, aspek kontruksional dalam gestur ekspresif yang ditunjukkan oleh Anwar diisyaratkan oleh mata dan mulut. Kemudian fitur pendukung diisyaratkan oleh pemilihan dan penggunaan busana serta perlakuan terhadap properti untuk reka adegan.
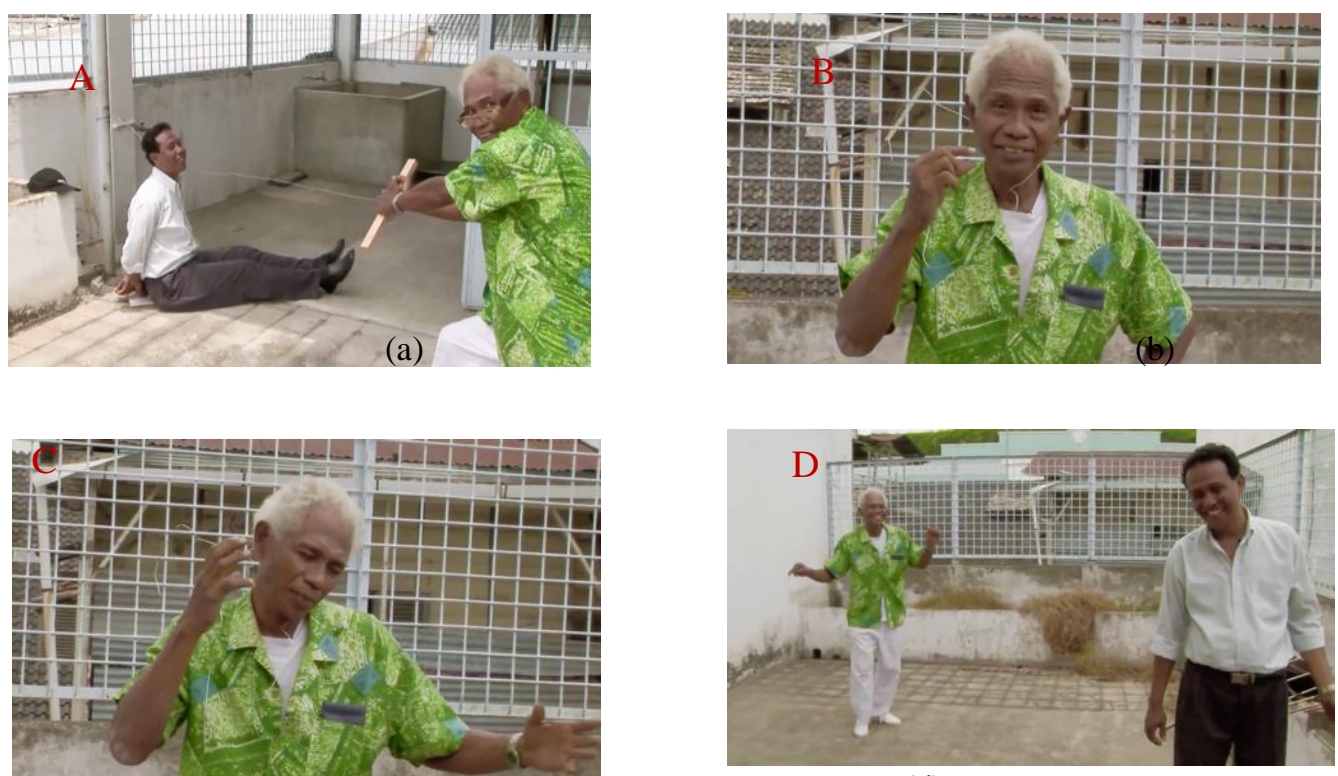

(c)

(d)

Gambar 7. a); b); c); d) Rangkaian frame Anwar dalam performativitas reka adegan pembunuhan (Sumber: The Act of Killing, Oppenheimer: 2012. Timeline: $\mathrm{A}=00.10 .08 ; \mathrm{B}=00.10 .38 ; \mathrm{C}=00.10 .45$; $\mathrm{D}=00.11 .12$ )

Keempat rangkaian frame menunjukkan pola gestur ekspresif Anwar secara berturut-turut. Frame A menjadi petunjuk bagi frame $\mathrm{B}, \mathrm{C}$, dan D tentang isyarat yang ditunjukkan Anwar melalui pergerakan mata, mulut, dan anggota tubuh lainnya (pergerakan anggota tubuh yang lain akan dianalisis berdasarkan pola gestur mimik). Tatapan fokus pada pola editing yang menunjukkan gestur ekspresif 
Anwar terkait dengan bentuk konstruksional. Pengamatan dilakukan secara berturut-turut dimulai dari frameA sampai dengan D dengan memerhatikan gestur dan fitur (khusunya suara yang dimunculkan dan berasal dari Anwar).

Page $\mid 96$

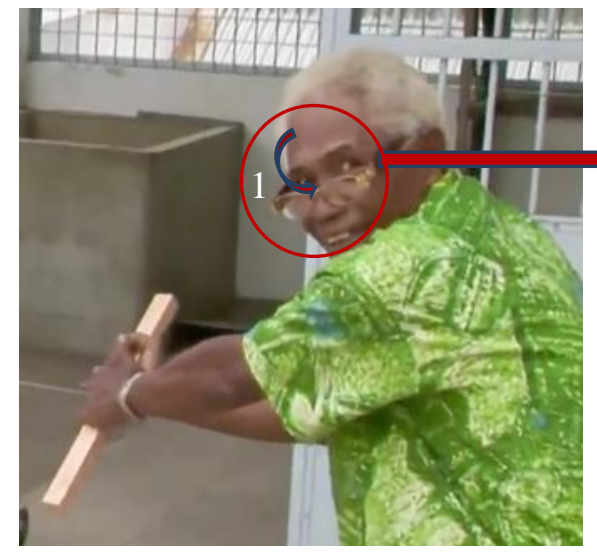

A

(a)

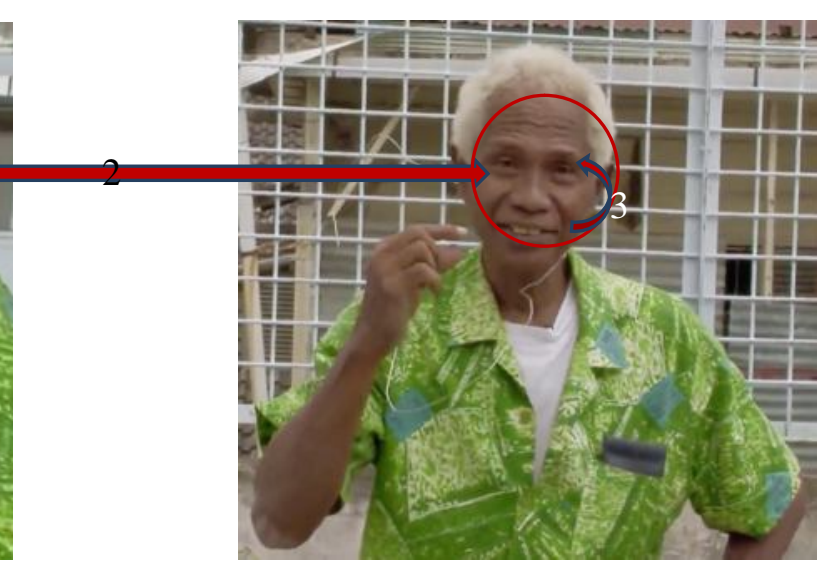

$\mathrm{B}$

(b)

Gambar 8. a) dan b) Ekspresi wajah Anwar menunjukkan persamaan pada gerak mata dan mulut di kedua frame

Perhatikan kembali unit gestur secara keseluruhan pada dua skema yang fokus pada masingmasing frame, yaitu frame A dan frame B. Tahap pembacaan dimulai pada skema Frame A dengan tatapan yang mengarah pada mata dan mulut Anwar. Anwar menggerakkan kepala menoleh ke arah kamera. Gerakan mata dan mulut Anwar simultan dengan suara yang keluar dari mulutnya. Selama 6 detik mata dan mulut Anwar terbuka, dan tertawa sambil berbicara. Tatapan mengikuti arah mata dan gerak mulut Anwar yang menoleh sambil tersenyum. Pola editing menampilkan adegan peragaan pembunuhan yang dilakukan Anwar. Dalam frame itu terdapat Anwar dan seorang aktor lain yang menjadi objek Anwar untuk melakukan reka adegan. Karena tidak ada zoom in yang difokuskan terhadap objek tertentu (oleh sudut pandang editing), maka arah tatapan secara berturut-turut ditujukan pada mata, mulut, dan gerak tubuh lain. Selain itu, properti yang digunakan dan berada di sekitar anwar juga menjadi sasaran tatapan. Sudut pandang editing memberikan ruang secara menyeluruh kepada Anwar untuk mempertunjukkan adegan. Pada frame ini tercipta ruang protosemantic, dimana tatapan dapat dengan mudah menciptakan makna terhadap gestur (gerak ekspresif) dan fitur (suara dan properti) karena sudut pandang visual yang menyeluruh. Fokus pembacaan yang ditujukan secara spesifik terhadap gestur ekspresif dengan bentuk konstruksional, diarahkan pada tatapan deictic untuk memahami ekspresi wajah dan suara Anwar. Suara Anwar yang menjelaskan tentang bagaimana pembunuhan itu berlangsung terdengar cukup lugas, datar, dan tidak nampak traumatik di dalamnya. Suara ini menjadi petunjuk bahwa kondisi Anwar pada saat mempergakan adegan pembunuhan adalah normal bahkan cenderung senang.

\section{KESIMPULAN}

Tiga hal yang menjadi petunjuk dan melekat sebagai gestur dan fitur adalah: (1) pergerakan kepala, tangan, dan kaki (2) pergerakan pada terjadi sebagai gestur ekspresif mata dan mulut, dan (3) pergerakan terjadi sebagai gestur mimik yang fokus pada tangan dan kaki. Adanya tiga gerakan yang fokus pada rangkaian gestur yang berpusat pada kepala, tangan, dan kaki beserta fitur yang melekat padanya memberikan petunjuk sebagai berikut: (1) kepala dan kaki Anwar menunjukkan gerakan tentang rangkaian pembunuhan sehingga gerakan ini menjadi dasar bagi konstruksi adegan; dan (2) konstruksi adegan diciptakan karena diperlukan sebagai salah satu bentuk performativitas. Terakhir, 
pembacaan menghasilkan pemahaman tentang korelasi antara gestur dan fitur (sebagai teks film) dengan narasi. Gestur dan fitur menjadi dua unsur penting sebagai petunjuk adanya kebenaran dalam The Act of Killing sebagai tipe dokumenter yang bersifat performatif. Dalam hal ini dapat ditarik kesimpulan bahwa petunjuk kebenaran dalam dokumenter performatif terletak pada bagaimana tatapan penonton mengikuti petunjuk gestur dan fitur yang melekat di sepanjang alur dan plot. Tatapan ini merupakan pangkal pemahaman terhadap kebenaran yang merujuk pada petunjukpetunjuk filmis hingga diperoleh keterpercayaan terhadapnya (kebenaran).

\section{DAFTAR PUSTAKA}

Aufderheide, P., 2007.Documentary Film a Very Short Introduction, New York: Oxford University Press

Beattie, K., 2004.Documentary Screen Non-Fiction Film and Television, New York: Palgrave

Bergman, T., 2004.Personal narrative, dialogism, and the performance of "truth" in complaints of a dutiful daughter. Journal of Text and Performance QuarterlyVol. 24, No. 1, January, pp. 3-20

Bernard, S.C., 2007.Documentary Storytelling, Oxford: Elsevier

Blumenberg, R.M., 1977.Documentary Films and the Problem of "Truth". Journal of the University Film Association, Vol. 29, No. 4, pp. 19-22

Bondebjerg, I., 2014.Documentary and Cognitive Theory: Narrative, Emotion and Memory. Journal of Media and Communication, Volume 2, Issue 1, pp. 13-22

Bordwell, D., 1985.Narration In The Fiction Film, Wisconsin: The University of Wisconsin Press.

and R. Burton Palmer (ed), 1989.Historical Poetic of Cinema (The Cinematic Text: Methods and Approaches. Georgia State Literary Studies No. 3, p. 369

and Carroll, N., 1996, Post-Theory: Reconstructing Film Studies, Wisconsin: The University of Wisconsin Press

1991.Making Meaning: Iinference And Rhetoric In The Interpretation of Cinema, Cambridge: Harvard University Press

Bruzzi, S., 2006, New Documentary ( $2^{\text {nd }}$ edition), New York: Routledge

Buckland, W., 2004.The Cognitive Semiotics of Film, Cambridge: Cambridge University Press

Carroll, N., 1997.The Essence of Cinema. Philosophical Studies: An International Journal for Philosophy in the AnalyticTradition, Vol. 89, No. 2/3, The American Philosophical Association Pacific Division Meeting (Mar., 1998), pp. 323-330 1996.Theorizing the Moving Image, Cambridge: Cambridge University Press 2003.Engaging the Moving Image, New Haven\&London: Yale University Press

Chare, N. and Liz Watkins (2015).Introduction: gesture in film, Journal for Cultural Research, 19:1, 1-5

David, Marian. 2012.Lehrer on Trustworthiness and Acceptance, Philos Stud (2012) 161:7-15 
De Caro, M. and E. Terrone, 2016, the View From Outside: On A Distinctively Cinematic Achievement, Philosophy and Social Criticism, 2016, Vol. 42(2), pp. 154-170

Eisenstein, S. 1969.Film Form, San Diego: A Harvest Book

Ellis, J.C., 1989.The Documentary Idea: A Critical History of English-Language Documentary Film and Video, New Jersey: Prentice Hall

Hardin, Russell.Trustworthiness, The University of Chicago Press: Ethics, Vol. 107, No. 1 (Oct., 1996), pp. 26-42

Hilderbrand, L. 2009,.Introduction Experiment in Documentary: Contradiction, Uncertainty, Change. Millenium Film Journal; Spring; 51; ProQuest Research Library; p. 2

Kendon, A. 2004. Gesture: Visible Action as Utterance. Cambridge: Cambridge University Press

Lehar, S., 2003.The World in Your Head: A Gestalt View of the Mechanism of Conscious Experience, London: Lawrence Elbaum Associates Publisher

McCalman, I. dan Pickering, P. A., (ed), 2010.Historical Reenactment From Realism to the Affective Turn, London: Palgrave Macmillan

McLane, B.A, 2012.A New History of Documentary Film, New York: Continuum

McNaughton, C. (2015) Reading The Mass Violence In Indonesia 1965-1966 As A Form Of Primitive Accumulation, Inter-Asia Cultural Studies, 16:2, 292-305

McNeill, D. 2016. Why We Gesture: The surprising role of hand movements in communication. United Kingdom: Cambridge University Press

Nannicelli, T. and Taberham, P., 2014. Cognitive Media Theory, New York: Routledge

Nash, K, 2010.Exploring Power And Trust In Documentary: A Study of Tom Zubrycki's Molly and Mobarak. SDF 4 (1) pp. 21-33. Intellect Limited

Nichols, B., 2001.Introduction to Documentary, Bloomington: Indiana University Press 2008. Documentary Reenactment and the Fantasmatic Subject. Critical Inquiry, Vol. 35, No. 1 (Autumn), pp. $72-89$

Oppenheimer, J. 2012. The Act of Killing. Danish Film Institute

Otway, F., 2015.The Unreliable Narrator in Documentary. Journal of Film and Video 67, pp. 3-4

Plantinga, C.R., 1997.Rhetoric and Representation in Nonfiction Film, Cambridge: Cambridge University Press

2006.Cognitive Theory in Film Studies. College Literature, Vol. 33, No. 1, Cognitive Shakespeare: Criticism and Theory in the Age of Neuroscience (Winter), pp. 215224

2009.Moving Viewers: American Film and The Spectator's Experience, Berkeley: University of California Press

Persson, P., 2003.Understanding Cinema:A Psychological Theory of Moving Imagery, Cambridge: Cambridge University Press 
Pohlman A (forthcoming, 2014).Women, Sexual Violence and the Indonesian Killings of 1965-1966. London: Routledge

Renov, M., 1993.Theorizing Documentary, London: Routledge

Robbins, Blaine G.Probing the Links Between Trustworthiness, Trust, and Emotion: Evidence from Four Survey Experiments, Social Psychology Quarterly 2016, Vol. 79(3) 284-308

Rosenthal, A. (ed). 1988, New Challenge for Documentary: The Voice of Documentary, Berkeley: University of California

Rotha, P. and Breitrose, H. (ed). 1974, Documentary Diary. Film Quarterly, Vol. 27, No. 3 (Spring), pp. 52-54

Ruby, J., 1992. Speaking For, Speaking About, Speaking With, or Speaking Alongside: An Anthropologycal and Documentary Dilemma, Journal of Film and Video, Vol. 44, No. 1/2, International Issues (Spring andSummer), pp. 42-66

Sanders, W., 2012, The Aggie Will Come First Indeed. A Survey on Documentary Filmmakers Dealing with Participants. New Review of Film and Television Studies. Vol. 10, No. 3, September, pp. 387-408.

Stam, R., et al., 2005, New Vocabularies in Film Semiotics, London: Routlegde.

Wieringa, S. E. (2014) Sexual Politics As A Justification For Mass Murded In The Act of Killing, Critical Asian Studies, 46:1, 195-199

Wijaya, E., To See Die, Again: The Act of Filming and The Act of Killing, Parallax, 2016, Vol. 22, No. 1, 81-95.

Winston, B., 1999,Documentary: How the Myth Was Deconstructed, Wide Angle, Volume 21, Number 2, March, pp. 71-86.

Willis, G., Royston, P., \& Bercini, D. 1991. The Use of Verbal Report Methods In The Development And Testing of Survey Questionnaires. Applied Cognitive Psychology, 5, pp. 251-267.

Wolfe, C. 1997. Historicising The "Voice of God": The Place of Vocal Narration In Classical Documentary, Film History, Vol. 9, pp. 149-167.

Wright, Stephen., Trust and Trustworthiness, Philosophia (2010) 38:615-627

Zurbuchen, M. S., History, Memory, and the "1965 Incident" in Indonesia, Asian Survey, Vol. 42, No. 4 (July/August 2002), pp. 564-581)

Kroef, J. M. Van Der, How Dead is the Indonesian Communist party?, Communist Affairs, 1967, Vol.5(1), pp.3-9. 